\title{
EXTRACTION OF MACRONUTRIENTS FROM OKRA (Abelmoschus esculentus (L) moench) AS INFLUENCED BY SOME MULCH MATERIALS IN THE ACID SANDS.
}

W. UBI and V. E. OSODEKE

(Received 24 August, 2005: Revision Accepted 12 May. 2006).

\section{AESTRACT}

Two experiments conducted in September 1993 during the dry season and March 1994 during the wet season to evaluate the effect of two okra cultivars (Emerald Green and Clemson spineless), and four mulch materials: (oil palm bunch refuse, grass, wood shavings mulches and bare ground) were studied at College of Education Farm, Akamkpa, Cross River State, Nigeria. In both experiments, soil temperatures were similar in milch treatments; soil temperatures were reduced by about $2^{\circ} \mathrm{C}$ with the bunch refuse and up to $4.1^{\circ} \mathrm{C}$ with the wood shawings during the ory season planting. Compared to the unmulched plots. the macronutrients $(N, P, K, C a, M g)$ content of okra fruits and seeds were increased by the mulch treatments and were found to entrance macronutrient content, during the dry season. In the two experiments, bunch refuse was significantly outstanding in increasing the macronutrient content of both whole pod and seeds of okra. The implications of these results are discussed in light of okra nutrient.

\section{KEYMORDS: Macronutrients from okra and mulch materials}

\section{WTRODUCTION}

Investigations have shown that mulching improves the nutritive values of fruits and seeds through enhanced soil moisture conservation, reduced soil temperature and reduction of diseases, (Hartley 1977; Wilman of al 1999; Mussan and Leitch 2000)

Okra is among the most commonly grown vegetables throughout Nigeria becaus of its nutritive importance. mucilaginous orawing fruits, much liked in soups. The crop generally grows well under most Nigerian climatic conditions including the rainforest zone of Nigeria where the bimodal rainfall results in two distinct growing seasons (dry season September to December and wet season March to September).

The crop is grown on about 2 million hectares annually in Nigeria, (James1988; FMAWRRD, 1989). The immature, young pod is the edible part of this plant. The use of organic mulches has been reported to be suitable for weed control. conservation of soil moisture and can lead to good nutritive value (Powell 2004). For greater yield and quality, application of $60 \mathrm{~kg} \mathrm{~N} / \mathrm{ha}$; $20 \mathrm{Kg} \mathrm{K} / \mathrm{ha}$ will be required. (Adeiena, 1985; WHORT 1976 - 1986; Ayodele 1993 and Ubi, 2004).

The objective of this study is to determine the macronutrient content of okra pods and okra seeds of two okrat cultivars planted on bare soil and under the modifying in:iuence of three mulch materials in order to determine the suitability of the mulch materials. The three mulch materials are chosen because they are readily avaiiule and are organic wastes, which can be of economic use in vegetable production.

\section{MATERIALS AND METHODS}

The experiment was set up in Septernber 1993 and 1994 at the fam of the College of Education, Akamkpa which lies between $8^{\circ} 14^{\prime}$ and $8^{\circ} 20^{\prime} \mathrm{E}$ longitude $5^{\circ} 14^{\prime} \mathrm{N}$ and $5^{\circ} 18^{\prime} \mathrm{N}$ latitude with a rainfall over $2,000 \mathrm{~mm}$ in the rainforest vegetation, of the basement complex soil. The area was previously cropped with cassava followed by four years fallow in which Centrosoma puibescence and Panicum maxima (guinea grass) were the dominant fallow species. The site was manually cleared. allowed to dry for some days, then gathered together and removed. The plot size was $5 \mathrm{~m}$ x $5 \mathrm{~m}$. Plots were uniformly planted to okra at inter row spacing of $50 \mathrm{~cm}$ and intra-row spacing of $30 \mathrm{~cm}$ without tillage. The experiment was a $2 \times 4$ factorial, laid out in randomized complete block design (RCBD) with four replications. The cultivars were Emerald (green. smooth pods) and Clerrison Spineless (green, smooth ribbed pods). Four seeds of each cultivar of ckra were planted per hole and thinned to 2 plants about two weeks after seed germination

The treatments were oil palm bunch refuse, wood shavings, grass, and unrinulched soil. Mulch materials were applied shortly after seed planting at the rat of 5tha for each season of the experment.

Soil femperatures were recorded at $0800 \mathrm{hrs}$ and $16.30 \mathrm{hrs}$ daily at $5 \mathrm{~cm}$ depth, according to Iremiren (1982). Three months after sowing, the monthly soil moisture content in the plots was determined gravimetrically from September December 1993 and March - June 1994. At germination, plants were sprayed weekly for 4 weeks with cymbush (cypernethrine). E. C. insecticide at the rate of $5 \mathrm{~m} / 10$ litres of water for the control of flea beetles and other leaf-eating insects. Two weeks after planting N P.K. fertilizer (20: 10: 10) was applied at the rate of $200 \mathrm{~kg} / \mathrm{ha}$ by band placement, (NIHORT, 1986). At about $50 \%$ flowering, a second dose was applied by top dressing with urea $(46: 0: 0)$ at the rate of $50 \mathrm{~kg} / \mathrm{ha}$. Five plants were randomly sampled and lagged for the determination of macronutrient content in fresh pods and fresh seeds. A clean knife was carefully applied to the edges of the fresh pods diagonally to avoid any damage to the seeds. The pericarp was removed and seeds taken out from the placenta, washed and dried. From the harvest of the five plants, ten fresh pods from each mulch treatment were randomly selected and another 10 iresh pods were also selected and the fresh seeds removed and both were dried at a temperature of $70^{\circ} \mathrm{C}$ for 72 hours in Gallen Kamp forced air laboratory oven. Samples were then ground separately in a Thomas Willey Laboratory Mill Model 4, using a $5 \mathrm{~mm}$ mesh screen. The milled samples were then thoroughly mixed and stored in cellophane bags under dry condition for the chemical analysis, which was done with New Model Atomic Absorption spectrophotometer with printer, at Alabama Agricultural and Mechanical University. Normal, Alabama, U.S.A. 


\section{Statistical analysis}

Data were subjected to analysis of variance (ANOVA) and means compared by the use of Fisher's Least Significant

Difference (LSD) at $5 \%$ probability level.

Table 1: Meteorological condition at College of Education, Cross River State University of Technology, Akamkpa, Nigeria September 1993 - June 1994

\begin{tabular}{|c|c|c|c|c|c|c|c|c|c|c|}
\hline & Sept. & Oet. & Nov. & Dec. & $\operatorname{Jan}$ & Feh: & March & April & May & June \\
\hline Total raintall (mm) & 492.6 & 41.3 & 102.2 & 35.6 & 8.1 & 27.8 & 65.2 & 232.6 & 241.0 & 250.1 \\
\hline $\begin{array}{l}\text { Maximum } \\
\text { temperature (OC) }\end{array}$ & 35.4 & 26.5 & 32.7 & 316 & 34,8 & 35.2 & 34.7 & 32.9 & 31.6 & 30.2 \\
\hline $\begin{array}{l}\text { Minimum } \\
\text { Temperature (OC) }\end{array}$ & 32.6 & 24.3 & 18.7 & 21.7 , & 22.5 & 22.5 & 23.8 & 23.4 & 22.6 & 21.7 \\
\hline $\begin{array}{l}\text { Mean Radiation } \\
\text { (JiCm2/day }\end{array}$ & 1533.4 & 1561.2 & 1678.4 & 2519.7 & $\begin{array}{l}157 \\
4.7\end{array}$ & 1574.7 & 1578.2 & 17184 & 1671.6 & $1571.1 \mathrm{C}$ \\
\hline
\end{tabular}

\section{RESULTS}

The rainfall data collected about $30 \mathrm{~m}$ from the experimental site are shown in Table 1. Generally, by September 1993 and March 1994, the rainfall was sufficient to support crop growth.

\section{Soil Temperature and Soil Moisture content}

Compared with the unmulched soil, bunch refuse reduced the mean monthly soil temperature by about $2^{\circ} \mathrm{C}$ and up to $4.1^{\circ} \mathrm{C}$ in the wood shavings during the study period (Table 2). The temperatures were not significantly $(P<0.05)$ different between the mulch and unmulched treatments in the wet season planting and ranged from 30.1 $-30.4^{\circ} \mathrm{C}$ in the morning and $31.1-34.5^{\circ} \mathrm{C}$ in the evening. The percent moisture content in experiment. 1 declined sharply in all treatments from September to December (Table 2.) The lowest soil mioisture occurred generally in the unmulched soil in all the treatments by up to $1.3 \%$. Mulch materials were observed to conserve soil moisture to a similar extent, In experiment- 2, the \% soil moisture continued increasing sharply in all treatments from March to June. The treatments used in this study have provided ideal growth conditions through enhanced soil moisture conservation, reduced soil temperature, improved soil texture.

Table 2a: Soil temperature $\left({ }^{\circ} \mathrm{C}\right)$

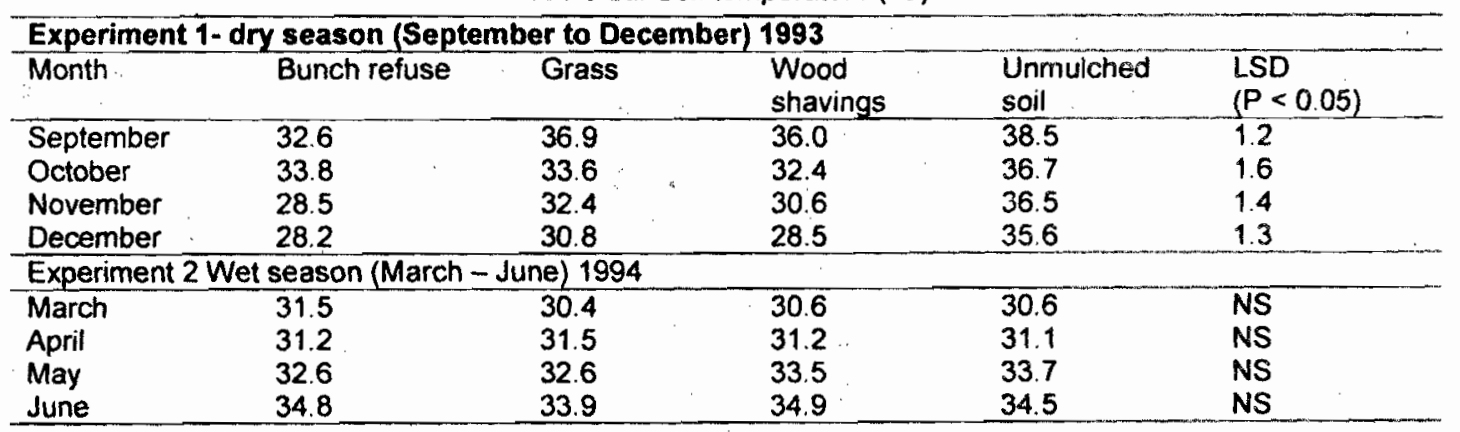

Table 2b: Soil Moisture Content (\%) Experiment 1 (Dry Season) 1993

\begin{tabular}{|c|c|c|c|c|c|}
\hline Month & Bunch refuse & Grass & $\begin{array}{l}\text { Wood } \\
\text { shavings }\end{array}$ & $\begin{array}{l}\text { Unmulched } \\
\text { soil }\end{array}$ & $\begin{array}{l}\angle S D \\
(P=0.05)\end{array}$ \\
\hline $\begin{array}{l}\text { September } \\
\text { October } \\
\text { November } \\
\text { December }\end{array}$ & $\begin{array}{l}5.2 \\
4.7 \\
4.1 \\
3.2 \\
\end{array}$ & $\begin{array}{l}4.3 \\
4.4 \\
4.0 \\
3.1\end{array}$ & $\begin{array}{l}4.7 \\
5.1 \\
4.3 \\
3.4 \\
\end{array}$ & $\begin{array}{l}3.4 \\
3.4 \\
2.3 \\
2.6 \\
\end{array}$ & $\begin{array}{l}0.7 \\
0.7 \\
\mathrm{NS} \\
\mathrm{NS} \\
\end{array}$ \\
\hline \multicolumn{6}{|c|}{ Experiment 2 (Wet season) 1994} \\
\hline $\begin{array}{l}\text { March } \\
\text { April } \\
\text { May } \\
\text { June }\end{array}$ & $\begin{array}{l}4.3 \\
5.3 \\
6.7 \\
6.8 \\
\end{array}$ & $\begin{array}{l}4.8 \\
4.6 \\
5.7 \\
5.4\end{array}$ & $\begin{array}{l}4.9 \\
4.8 \\
6.8 \\
6.9 \\
\end{array}$ & $\begin{array}{l}3.4 \\
3.7 \\
3.5 \\
3.6\end{array}$ & $\begin{array}{l}0.3 \\
0.8 \\
0.6 \\
\text { NS }\end{array}$ \\
\hline
\end{tabular}


Table 3a: Macronutrient (mg/Kg) content of okra fresh pods planted in September to December. 1993. Experiment 1 (dry season) September December 1993

\begin{tabular}{|c|c|c|c|c|c|}
\hline Cultivars & $\begin{array}{l}\text { Bunch } \\
\text { refuse }\end{array}$ & $\begin{array}{l}\text { Wood } \\
\text { shavings }\end{array}$ & Grass & $\begin{array}{l}\text { Unmulched } \\
\text { soil }\end{array}$ & $\begin{array}{l}\text { LSD } \\
(P<0.05)\end{array}$ \\
\hline
\end{tabular}

Emerald

Fresh pods (whole)

$\begin{array}{llllll}\mathrm{N} & 2.65 & 2.14 & 2.34 & 1.32 & 0.20 \\ \mathrm{P} & 62.0 & 43.0 & 54.0 & 31.0 & 3.60 \\ \mathrm{~K} & 302.0 & 253.0 & 295.0 & 151.0 & 21.00 \\ \mathrm{Ca} & 83.0 & 61.0 & 78.0 & 42.0 & 12.00 \\ \mathrm{Mg} & 57.0 & 48.0 & 51.0 & 26.0 & 6.20\end{array}$

Clemson spineless

\begin{tabular}{llllll}
$\mathrm{N}$ & 2.61 & 2.04 & 2.14 & 1.30 & 0.40 \\
$\mathrm{P}$ & 58.0 & 41.0 & 51.0 & 30.0 & 5.00 \\
$\mathrm{~K}$ & 286.0 & 248.0 & 257.0 & 112 & 10.00 \\
$\mathrm{Ca}$ & 73.0 & 55.0 & 76.0 & 34.0 & 4.00 \\
$\mathrm{Mg}$ & 52.0 & 46.0 & 50.0 & 25.0 & 4.00 \\
\hline
\end{tabular}

Table 3a: Macronutrient content of okra raw (mg/kg).

\begin{tabular}{llllll}
\multicolumn{5}{l}{ Experiment 2 Wet season) March- June 1994 } & \\
\hline Emerald & $\begin{array}{l}\text { Bunch } \\
\text { refuse }\end{array}$ & $\begin{array}{l}\text { Wood } \\
\text { shavings }\end{array}$ & Grass & $\begin{array}{l}\text { Unmulched } \\
\text { soil }\end{array}$ & $\begin{array}{l}\text { LSD } \\
\text { (P }<0.05)\end{array}$ \\
\hline $\mathrm{N}$ & 2.15 & 1.53 & 1.64 & 1.03 & 0.30 \\
$\mathrm{P}$ & 60.0 & 40.0 & 42.0 & 26.0 & 2.00 \\
$\mathrm{~K}$ & 185.0 & 152.0 & 158.0 & 91.0 & 6.00 \\
$\mathrm{Ca}$ & 75.0 & 58.0 & 60.0 & 36.0 & 2.00 \\
$\mathrm{Mg}$ & 51.0 & 64.0 & 48.0 & 25.0 & 2.00 \\
\hline & & & & & \\
$\mathrm{Clemson}$ & spinetess & & 1.42 & 0.81 & 0.60 \\
$\mathrm{~N}$ & 2.04 & 1.33 & 38.0 & 26.0 & 2.00 \\
$\mathrm{P}$ & 54.0 & 36.0 & 153.0 & 126.0 & 7.00 \\
$\mathrm{~K}$ & 171.0 & 145.0 & 56.0 & 31.0 & 4.00 \\
$\mathrm{Ca}$ & 68.0 & 51.0 & 45.0 & 24.0 & 3.00 \\
$\mathrm{Mg}$ & 47.0 & 42.0 & & & \\
\hline
\end{tabular}

Table 4a: Macronutrient content of fresh okra seeds (mg/ $\mathbf{k g})$

\begin{tabular}{|c|c|c|c|c|c|}
\hline Cultivars & $\begin{array}{l}\text { Bunch } \\
\text { refuse }\end{array}$ & Wood shavings & Grass & $\begin{array}{l}\text { Unmulched } \\
\text { soil }\end{array}$ & $\begin{array}{l}\text { LSD } \\
(P<0.05)\end{array}$ \\
\hline Emorald & & (Fresh okra seed & & & \\
\hline $\mathbf{N}$ & 2.15 & 1.08 & 1.64 & 1.02 & 0.05 \\
\hline$P$ & 51.0 & 40.0 & 48.0 & 35.0 & 5.00 \\
\hline K & 260.0 & 234.0 & 251.0 & 137.0 & 15.00 \\
\hline $\mathrm{Ca}$ & 72.0 & 34.0 & 68.0 & 36.0 & 10.00 \\
\hline $\mathrm{Mg}$ & 51.0 & 31.0 & 45.0 & 32.0 & 4.00 \\
\hline \multicolumn{6}{|c|}{ Clemson spineless } \\
\hline$N$ & 2.01 & 1.13 & 1.52 & 1.00 & 0.12 \\
\hline$P$ & 55 & 36 & 47.0 & 25.0 & 4.00 \\
\hline K & 296 & 249 & 286.0 & 139.0 & 10.00 \\
\hline $\mathrm{Ca}$ & 70 & 52 & 64.0 & 30.0 & 12.00 \\
\hline $\mathrm{Mg}$ & 51 & 42 & 46.0 & 24.0 & 4.00 \\
\hline
\end{tabular}


Table 4b: Macronutrient content of okra raw $(\mathrm{mg} / \mathrm{kg})$

\begin{tabular}{llllll}
\hline $\begin{array}{l}\text { Exporiment } \\
\text { Emerald }\end{array}$ & $\begin{array}{c}\text { Wet season) } \\
\text { Bunch } \\
\text { refuse }\end{array}$ & $\begin{array}{c}\text { March-June } \\
\text { Wood } \\
\text { shavings }\end{array}$ & Grass & $\begin{array}{l}\text { Unmulchod } \\
\text { soil }\end{array}$ & $\begin{array}{l}\text { LSD } \\
\text { (P < 0.05) }\end{array}$ \\
$\mathrm{N}$ & 2.02 & 1.41 & 1.62 & 0.8 & 0.20 \\
$\mathrm{P}$ & 47.0 & 36.0 & 40.0 & 31.0 & 4.00 \\
$\mathrm{~K}$ & 162.0 & 143.0 & 148.0 & 136.0 & 5.00 \\
$\mathrm{Ca}$ & 72.0 & 53.0 & 60.0 & 32.0 & 7.00 \\
$\mathrm{Mg}$ & 47.0 & 41.0 & 45.0 & 28.0 & 3.00 \\
\hline $\mathrm{Clemson}$ spineless & 1.84 & 1.02 & 1.24 & 0.63 & 0.22 \\
$\mathrm{~N}$ & 52.0 & 32.0 & 34.0 & 27.0 & 2.00 \\
$\mathrm{P}$ & 162.0 & 131.0 & 142.0 & 80.0 & 9.00 \\
$\mathrm{~K}$ & 61.0 & 45.0 & 48.0 & 22.0 & 3.00 \\
$\mathrm{Ca}$ & 43.0 & 24.0 & 28.0 & 21.0 & 4.00 \\
$\mathrm{Mg}$ & & & & & \\
\hline
\end{tabular}

\section{Macronutrient content of fresh Okra pods}

The results of macronutrient content of okra as influenced by mulch treatments during the dry season planting, September to December 1993 are presented in Tables $3 a$ and $b$. Mulching exerted significant $(P<0.05)$ influence on the macronutrient content of fresh okra pods. Highest macronutrients (N 2.65; P 62.0; K 302.0; Ca 83.0 and $\mathrm{Mg} \mathrm{57.0)} \mathrm{mg} / \mathrm{kg}$, on the average, was obtained from the Emeraid cultivar where bunch refuse was applied and this was significantly $(P<0.05)$ higher than those of the other mulch treatments and those of Clemson spineless. Wood shavings performed poorly within the mulch treatments and the macronutrient content of fresh okra pods obtained from these plots, on the average, were significantly low, but higher than the unmulched plots. While the macro nutrient content of fresh pods between grass and wood shavings treatment were slight, the macronutrient content between bunch refuse and unmulched soil was doubled in the two okra cultivars (Tables $3 a-b$ ).

In experiment 2, wet season planting (March - June 1994), the muich treatment effect was significant $(P<0.05)$ on macronutrient content of okra fresh seeds (Tables $4 a \&$ b) The total macronutrients in Emerald cultivar in plots that received bunch refuse treatment were sianificantly higher than those of the other mulch treatments and those of Clemson Spineless cultivar. While the macronutrient differences due to mulch treatments of wood shavings and grass had become virtually reduced, macronutrients differences imposed by bunch refuse compared with unmulched plots was becoming more emphasized. Thus, plots that received bunch refuse treatment had on the average, (N 2 15;P 60 0; Ca 75.0 and $\mathrm{Mg} 51.0$ ) $\mathrm{mg} / \mathrm{kg}$, and these were significantly $(P<0.05)$ more than double that of unmulched plots in the two cultivars. Wood shavings treatment had the lowest macronutrient content in both cultivars during the wet season.

\section{Macronutrient content of fresh okra seeds}

Tables $4 a$ and $4 b$ show the macronutrient contents of fresh okra seeds as influenced by mulch treatments during dry season (experiment 1) and wet season (experiment 2). Mulching exerted significantly $(P<0.05)$ influenced on the macronutrient content of fresh okra seeds in the two cultivars during the study period. Wood shavings had the least

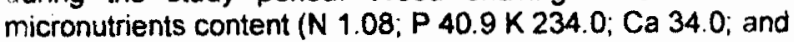

mg 31.0) $\mathrm{mg} / \mathrm{kg}$ from emerald cultivar, in experiment 1, and ( N 1.41, P, 36.0, K 143.0, Ca 53.0 and $\mathrm{Mg} \mathrm{41.0)} \mathrm{mg} / \mathrm{kg}$ in experiment 2 and their values were significantly low, but higher than those of unmulched plots in both dry and wet season (experiments $1 \& 2$ ), and in the Clemson Spineless cultivar. Bunch refuse treatment throughout the experimental periods maintained the highest macronutrient content in the fresh okra seeds (N 2.15, P 58.0, K 260.0, Ca 72.0 and $\mathrm{Mg}$ $51.0) \mathrm{mg} / \mathrm{kg}$ from the Emerald cultivar and their values were significantly higher than those of other mulch treatments and of Clemson Spineless cultivar.

\section{DISCUSSION}

A similar soil temperature in the mulched and unmulched treatments in experiments 2 (wet season) March - June suggests that the prevalent high rainfall (Table 1) suppressed the impact of the incident solar radiation on soil temperature. On the contrary, low rainfall in the early months of the dry season planting favoured reflection of solar radiation by the mulched materials and an attendant reduction in soil temperature by different degrees. Again, the differences between the mulched treatments were more apparent in the dry season planting.

The differences between macronutrients composition in the fresh okra pods and seeds and within mulched treatments may be partly due to soil temperature effects as treatment with lower soil temperature generally performed better through enhanced soil moisture conservation, thereby improving the nutritive value of fruits and seeds, (Hartley, 1977). Cook, (1991) reported that slower phase of mineral absorption by plant cells was sensitive to soil temperature and anaerobiosis.

In spite of the fact that mulching did not lower the soil temperature in the wet season, in the second experiment, it however improved the soil moisture regime during the dry season, probably by directly decreasing the losses caused by evaporation losses might have accompanied the higher soil temperature of the unmulched soil in the first planting season leading to water - stress and eventual impairment of assimilate and macronutrients translocation to fresh okra pods and seeds. Wilman et al (1998) reported some differences between eight grasses within the Lolium-Fesfuca complex when sown in conditions of severe water shortage. 
Gates (1988) reported that, in tomato plants, at least the supply of phosphorus to plant cells was drastically reduced by moderate water - stress. In both experiments, however, the pattern of partition of assimilates between the roots and the shoots of mulched and unmulched plants were similar. Hence the overall stress suffered by plants of the unmulched soil was not detrimental enough to favour either the macronutrients within the root surface (soil solution) or within the tissue cells of okra. Although some mulch materials were bound to create a negative effect of immobilization, in which nitrate nitrogen is used up by microflora, but in this study, a very positive effects was observed due to the application of the mulch treatments bringing about mineralization. The availability of N, P, K, Ca and Mg within the mulch treatments therefore became a function of their concentration.

The use of wood shavings as mulch material gave rise to immobilization process in the soil in which microbial organisms used up nitrate nitrogen in the soil during breaking down processes and can account for the low level of $\mathbf{N}$ recorded in wood shaving treatment. It is believed in this study that during mineralisation by microflora and immobilization process within the wood shavings medium, other macronutrients, apart from $\mathrm{N}$, might have been lost. This might have accounted for the low values of macronutrients obtained by wood shaving treatments in both fresh okra pods and seeds, throughout the study period. In a similar experiment, Hewitt. (1991), reported that impaired reduction of $N$ is associated with deficiencies of several elements including $\mathrm{Ca}, \mathrm{K}$ and $\mathrm{Mg}$.

Emerald cultivar showing more macronutrients values in all mulch treatments than Clemson spineless is suggested to be due to genetic improvement of the cultivar to absorb macronutrients sufficiently and stored some within plant tissues. Similar result was reported by Hassan, and Leitch, (2000), in their study on the influence of seedling density on content and uptake of N.P.K in linseed, (Linum usitatissimum, $L$ )

\section{CONCLUSION}

The results from this study has shown that the macronutrients content of okra cultivars follow closely the treatment applied, the genetic composition, rate of absorption of assimilates from the soil and soil moisture regime.

Environmental factors - high temperature, heavy rainfall that may result to leaching of exchangeable cations, light intensity, drought and the nature of mulch material used could exert a significant effect on the absorption and retention of macronutrients by plant cells and root surfaces in the soil and was suggested to be responsible for the macronutrients levels in the plant tissues reported in this study.

Apparently the rate of macronutrients absorption rather than transport limits macronutrients accumulation in the fresh okra pods and seeds. The available report from this study shows that commercial production of okra will be better in the experiment 1 September to December (dry season) with Emerald cu'tivar for high nutritional value. Much more critical work needs to be done before the influence of soil moisture, temperature and mulch materials on the macronutrients content of fresh okra pods and seeds could be satisfactorily assessed.

\section{REFERENCES}

Adelana, B. O., 1985. Effect of N. P and $K$ fertilizer on yield of okra in South western Nigeria. Samaru Journal of Agric. Resource. National Institute for Horticultural Research. Ibadan. 3(2): $67-72$.
Ayodela O. J., 1993. Yield responses of okra (Abelmoschus esculentus (L) moench) to N,P and $K$ fertilizers NIHORT Research bulletin: No:13

Cook, G. M., 1991. Okra production. A review of plant physiology 22: $97-120$.

Federal Ministry of Agriculture water resources and rural development, 1989. Fertilizer use and management practices in Nigeria series No. 2: W. O. Enwezor ed.) Fertilizer procurement and distribution, Lagos.

Gate, C. T., 1988. In water deficit and plant growth. (T. J. Kozlewski ed.) 11: 135-190. Academy Press. New York.

Hartley, G. W., 1977. The oil palm (Eleasis guneensis Jacob,) Longman, London

Hewitt E.., 1991. In nitrogen nutrition of the plant, (E. A. Kirsky ed.) The Waverly Press, Leeds. Pp. 78-103.

Hussan, F. U. and Leitch M. H., 2000. Influence of seedling density on content and up take of $N$. $P . K$ in Linseed. (Linum usitatissionum, L.) Journal of Agronomy and Crops Science. 185. $193-199$.

James A. T., 1998. Post harvest biodeterioration of okra (Abelmaschus esculentus (L) Moench) Ph.O Thesis, University of Ibadan, Nigeria.

Longman, P., 1989. In Ecology aspect of the mineral nutrition of plants., Blackwell Oxford. 15: $309-322$

NIHORT - National Institule for Horticultural Research, 1986. Advances in fruits and vegetable research at NIHORT. A commemorative publication to mark the $10^{\text {th }}$ Anniversary of NIHORT, Ibadan, Nigeria.

Ubi, W., 2004. Responses of Okra (Abelmoschus esculentus (L) moench) to some mulch materials. Global Journal of Agricultural Science. 3(1 and 2): 53-57.

Wilman, D. Dong, K. H., Jin, Z. L., 1999. Growth, yield and quality of a range of grasses in a continental climate. Experimental Agriculture 35: 55 - 62 . 